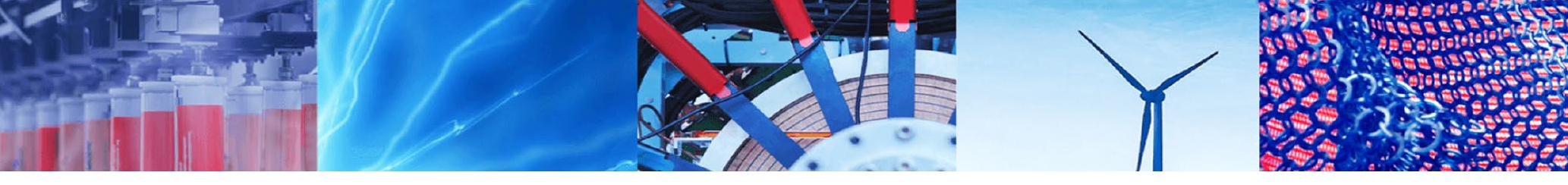

Case Study

\title{
Nitrogen recovery via aquaponics in Nepal: current status, prospects, and challenges
}

\author{
Rishav Adhikari $^{1} \cdot$ Sriyanka Rauniyar $^{1} \cdot$ Nishan Pokhrel $^{2} \cdot$ Amrita Wagle $^{3} \cdot$ Takeshi Komai $^{4} \cdot$ Shukra Raj Paudel $^{1,5}$
}

Received: 6 April 2020 / Accepted: 30 May 2020 / Published online: 9 June 2020

(c) Springer Nature Switzerland AG 2020

\begin{abstract}
Aquaponics is a bio-integrated system that couples recirculating aquaculture with hydroponics. Existing aquaculture has been a continuous source of environmental degradation; however, minimal concern has been documented toward its waste management. This paper aims to review the fundamental aspects of aquaponics, its components, types and influencing factors, and also to estimate potential nitrogen recovery from aquaponics. This review also explores the nitrogen transformation pathway and discusses potential challenges for aquaponics in Nepal. The estimated the nitrogen recovery potential of aquaponics in Nepal are 3509 tonnes (t) and $7157 \mathrm{t}$, equivalent to $7628 \mathrm{t}$ and $15558 \mathrm{t}$ of urea fertilizer for the years 2020 and 2030, respectively. Globally, nitrogen loss from aquaculture was estimated to be $7.52 \times 10^{6} \mathrm{t}$ for 2016. Developing countries like India, Bangladesh, Nigeria, etc. are also major source of existing nitrogen loss from aquaculture. For environmental and production sustainability, wastewater utilization via aquaponics is crucial, therefore, needs global attention and policy formulation. Identification of isotopic signature or abundance of stable isotopes in aquaponics helps find the exact pathway of nitrogen transformation in the system.
\end{abstract}

Keywords Aquaponics · Aquaculture wastewater - Nitrogen transformation · Nitrogen recovery

\section{Introduction}

Food and nutritional security has become one of the critical global issues in the modern society. Soaring urbanization and population demands has caused to increase resource supply from limited production area. Nepal as a developing country significantly relies on agriculture and the effects of climate change on such graniferous lands are detrimental to people's welfare and economic development [33]. In this county, aquaculture and farming (for fish and vegetables) are prevalent among farmers. Aquaculture has become a major source of global fish protein for the world population and globally fish food is consumed at about $19.2 \mathrm{~kg}$ per capita per year [18]. In Nepal, aquaculture comprises $66.83 \%$ of its total fish production, and has become the fastest growing industry with average annual growth rate of $11.10 \%$ per annum [18, 40]. Vegetables are cultivated in minor section of cultivable lands in Nepal-insufficient to meet the national demand. Farming and aquaculture are one of the major sources of food supply and employment opportunities for which the country possesses substantially favorable environment. Traditional framing practices are required to replace with alternative production practices with respect to pollution control and potential nutrient recovery. Aquaculture is considered as one of the major fish food production

Shukra Raj Paudel, srpaudel@ioe.edu.np| ${ }^{1}$ Department of Civil Engineering, Pulchowk Campus, Institute of Engineering, Tribhuvan University, Pulchowk, Lalitpur, Nepal. ${ }^{2}$ Department of Civil and Environmental Engineering, Virginia Polytechnic Institute and State University, Blacksburg, VA, USA. ${ }^{3}$ Department of Medical Microbiology, Nobel College, Pokhara University, Sinamangal, Kathmandu, Nepal. ${ }^{4}$ Department of Environmental Studies for Advanced Society, Graduate School of Environmental Studies, Tohoku University, Sendai 9808579 , Japan. ${ }^{5}$ Department of Environmental Engineering, College of Science and Technology, Korea University, Sejong, Republic of Korea. 
industries which consumes and release huge amount of nitrogen [22]. Higher nutrient concentration of aquaculture effluent stimulates algae growth that subsequently results in eutrophication and hypoxia in water bodies [39]. On the other side, antibiotic resistance used in aquaculture to lessen diseases dissemination causes chemical pollution [22]. And, aquaculture is also a considerable source of nitrous oxide: a potent greenhouse gas $[39,40]$. Moreover, excessive use of chemical fertilizers causes heavy metal accumulation, water eutrophication, nitrate accumulation, soil degradation, and release of nitrous oxide and nitrogen into the atmosphere $[40,50]$. Therefore, sustainable approaches for efficient aquaponic production (fish and plant biomass) and management of nitrogen (nitrogen, nitrous oxide) loss using new techniques have been realized for Nepalese context too. In parallel, nutrient recovery from aquaculture wastewater with sustainable organic farming can also provide clean water (less nitrate and ammonium concentration) for recirculating aquaculture tank.

Wastewater from aquaculture contains nutrients like nitrogen and phosphorus, which can be utilized for the growth of plant species. Past studies documented that aquaponics is a sustainable approach for nutrient utilization from aquaculture wastewater with ensuing organic production of vegetables $[28,51,58,63]$. However, this technology is in emerging practice, and has many challenges. In aquaponics, there exist a symbiotic relationship among fishes, microorganisms and plants. Aquaculture wastewater can supply most of the nutrients required for plants provided that the optimum ratio between daily feed input and plant growing area is to be maintained [42]. In fact, the waste produced by fish serves as manure for the plants which eventually becomes convenient for fish on recirculation [57]. Aquaculture wastewater has high amount of nitrogen content in the form of total ammonia nitrogen (TAN), which undergoes nitrification via nitrifying bacteria resulting nitrate $\left(\mathrm{NO}_{3}^{-}\right)$(Fig. 1). Nitrate, a basic nutrient for plants, is assimilated by plants resulting in clear water essential for fish $[41,59]$. Plants like tomato (Sonalum lycoperiscum) and lettuce (Lactuca sativa) have very good nutrient uptake from aquaponics system which also results in potential reduction of $\mathrm{N}_{2} \mathrm{O}$ emission $[22,40$, $41,59]$. Thus, aquaponics is not only considered a production alternative but also is considered as a promising means of wastewater treatment system.

Aquaculture wastewater, however, contains nutrients like nitrogen (N), phosphorus $(P)$ and Carbon (C) (12, [35]; this paper focuses only on nitrogen transformation and its potential recovery. Despite of its several production and environmental benefits, aquaponics practice is in emerging phase in Nepal. Therefore, this paper has placed the emphasis potentially to promote the application of aquaponics as an alternate production system for fish and vegetables in Nepal. The overarching goal of this paper is to estimate potential nitrogen recovery from aquaponic

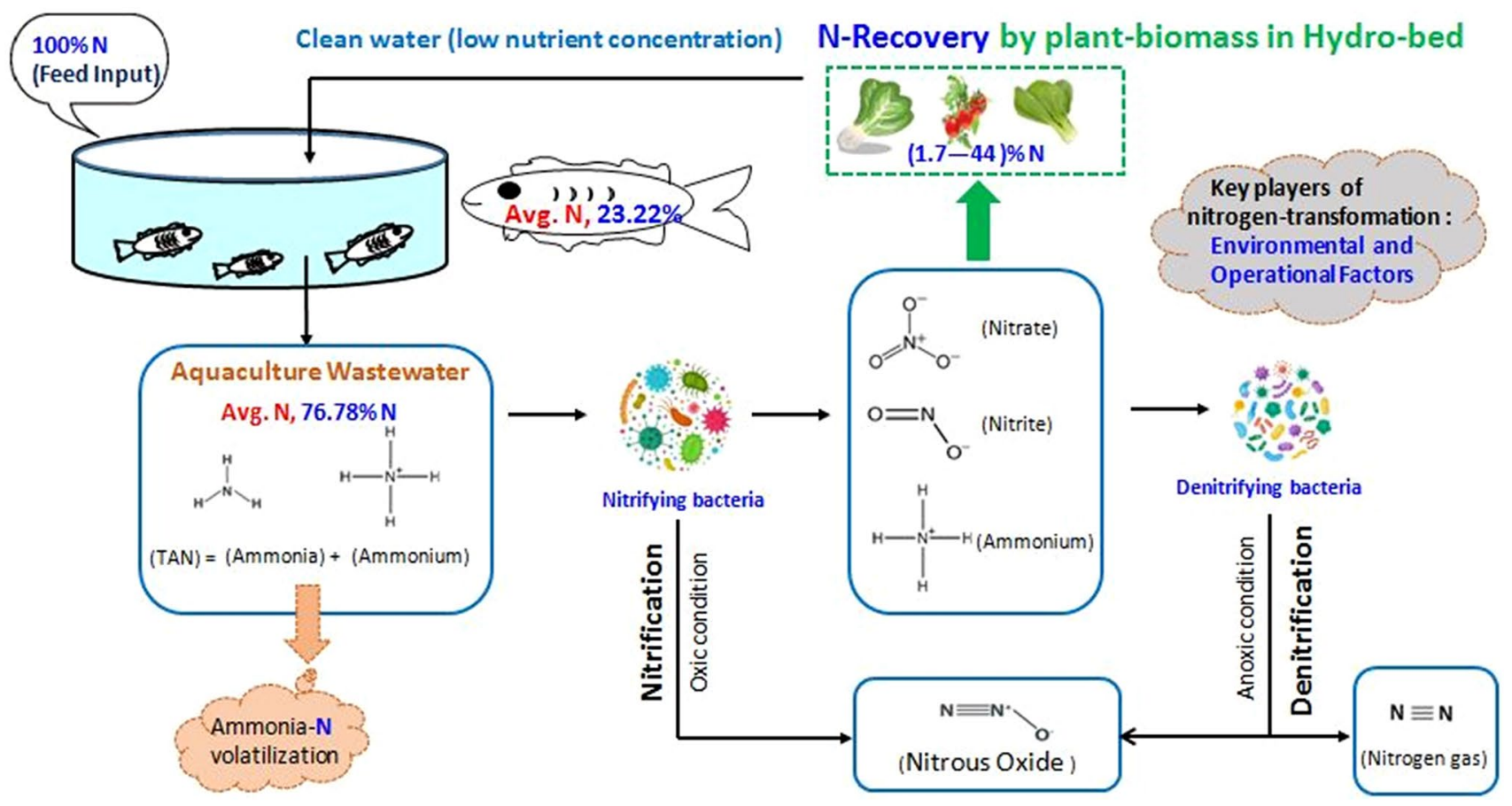

Fig. 1 Symbiotic relationship among fish, microbes and plants in aquaponics 
system in Nepal and in major continents of the world, and also to illustrate nitrogen transformation with fundamental science and aspects of aquaponics. This study also briefly discusses potential reduction of $\mathrm{N}_{2} \mathrm{O}$ emission, status, and possibilities and challenges of aquaponics in Nepal.

\section{Principle of aquaponics}

Aquaponics is a freshwater ecosystem which is made up of interactions between its biotic (living) components which include fish, plants and bacteria, and abiotic (non-living) components that comprise of water, air, and growing media (Fig. 1). Humans nurture fishes in a fish tank by supplying the required amount of feed. Fishes excrete waste into water which contains high amount of ammonia after consuming supplied feed. Bacteria and other microorganisms transform those wastes into nutrient rich and watersoluble fertilizer containing nitrate and ammonium which are commonly used by the plants for their growth. Plants uptake nitrogen and it results in producing relatively clean wastewater. Finally, thus produced clean water is recirculated in the fish tank. The scientific idea of aquaponics remains same in all types of aquaponic system.

In aquaponic system, the excreted TAN from fish is oxidized to nitrite $\left(\mathrm{NO}_{2}{ }^{-}\right)$and nitrate $\left(\mathrm{NO}_{3}{ }^{-}\right)$by ammonia-oxidizing bacteria $(\mathrm{AOB})$ and nitrite-oxidizing bacteria (NOB), respectively (Fig. 1), which consequently lowers ammonia and nitrite toxicity in the fish tank. Nitrate is assimilated by the plants that enhances the nitrogen use efficiency (NUE), and thus ultimately creates better environment for fish in the aquaculture tank $[58,60]$. The nitrous oxide $\left(\mathrm{N}_{2} \mathrm{O}\right)$, a potent greenhouse gas, can be minimized or managed to reduce through aquaponic system by altering plant species and their density thereby helping lower nitrogen species concentration for nitrification and denitrification process $[22,40,41]$.

\section{Components of an Aquaponic system}

\subsection{Biological components}

\subsubsection{Plants}

Plants, hydroponic component in aquaponics, are cultured in a grow bed with nitrate rich water. Plants are important in maintaining aquaponics cycle since, they lower nitrate and ammonia concentration by utilizing for their own growth. Optimum utilization of excess nutrients present in the fish tank is the main goal of culturing plants in aquaponics. In point of commercial view, the plants should generate highest level of income per unit area of culture. Therefore, selection of plant species is key to achieve water quality for recirculation; however, it also depends upon nutrient concentration and stocking density of fish [5]. Both leafy vegetables and fruits can be harvested in aquaponic systems [2]. Past studies have reported that culinary vegetables are economically suitable because of their growth performance, high demand and market values and availability [43].

Common vegetables harvested in aquaponic system are listed in Table 1. Leafy vegetables and herbs like cilantro, mint, parsley okra, etc. can also be grown in an aquaponic system. Fruiting crops like tomato, eggplant, pepper, strawberries are preferred for high nutrient concentration, and are only suitable for well-established and large-scale aquaponics [2, 38, 43]. In aquaponic systems, flowers like marigold and zinnia have been successfully harvested, and have potential to grow medicinal herbs too [43]. Hydroponic performance of anaquaponic system is remarkably affected by the plant species. Higher root surface area of plants is crucial to abundance of nitrifying bacteria and higher nitrogen transformation and utilization efficiencies (NUE) of the aquaponic system. Nitrogen uptake capacity of plants also plays a vital role in avoiding the accumulation of $\mathrm{NO}_{3}{ }^{-}$in aquaponics $[21,41]$.

\subsubsection{Fishes}

Fishes, a major source of nutrient in aquaculture wastewater, supply nutrients to plants on the grow bed. And, they are reared and nurtured in the fish tank with required amount of water. Protein and nitrogen content in the fish biomass varies among the fish species resulting in variation in aqueous nitrogen after assimilation in the fish tank $[18,22]$. This eventually results in variation of nutrient; especially nitrate $\left(\mathrm{NO}_{3}{ }^{-}\right)$in the hydroponic component. Diverse fish species (both warm and cold water) depending on their performance have been adopted/studied in aquaponic systems [8], some of which includes: Tilapia (Oreochromis niloticus), Nile tilapia (Oreochromis niloticus), Red tilapia (Oreochromis aureus $\times$ Oreochromis mossambicus), Catfish (Siluriformes), Trout (Oncorhynchus mykiss), Perch (Perca), Common carp(Cyprinus carpio), Koi carp, Largemouth bass (Micropterus salmoides), Murray cod (Maccullochella peelii), Mullet (Mugilidae), Pacu (Colossoma macropomum) $[2,8,38,43]$. Fish species that can resist high stocking density are expected to do well in aquaponic farming [43]. Among several fish species, Tilapia (Oreochromis niloticus) is most commonly reared fish species in aquaponics because of their high tolerance to wide range of temperature, salinity, low dissolved oxygen levels, and high ammonia concentration [8]. 
Table 1 List of common vegetables harvested in aquaponic systems

\begin{tabular}{|c|c|c|c|c|c|}
\hline Plant species & Scientific name & $\mathrm{pH}$ & Temperature range $\left({ }^{\circ} \mathrm{C}\right)$ & $\begin{array}{l}\text { Recommended } \\
\text { aquaponic method }\end{array}$ & References \\
\hline Basil & Ocimum basilicum & $5.5-6.5$ & $18-30(20-25)$ & $\mathrm{MB}, \mathrm{NFT}, \mathrm{FRT}$ & Somerville et al. [53] \\
\hline Cauliflower & Brassica oleracea var. botrytis & $6.0-6.5$ & $20-25$ & MBT & \\
\hline Lettuce & Lactuca sativa & $6.0-7.0$ & $15-22$ & MB, NFT, FRT & \\
\hline Cucumber & Cucumis sativs & $5.5-6.5$ & $22-28 / 18-20^{a}$ & MBT, FRT & \\
\hline Eggplant & Solanum melongena & $5.5-7.0$ & $22-26 / 15-18^{a}$ & MBT & \\
\hline Peppers & Capsicum & $5.5-6.5$ & $22-30 / 14-16^{\mathrm{a}}$ & MBT & \\
\hline Tomato & Solanum lucpersicum & $5.5-6.5$ & $(22-26) /(13-16)^{a}$ & MBT, FRT & \\
\hline Beans and Peas & - & $5.5-7.0$ & $22-26 / 16-18^{a}$ & MBT & \\
\hline Head Cabbage & Brassica oleracea & $6.0-7.2$ & $15-20$ & MBT & \\
\hline Broccoli & Brassica oleracea var. italic & $6.0-7.0$ & $13-18$ & MBT & \\
\hline Swiss Chard & Beta vulgaris & $6.0-7.5$ & $16-24$ & MBT, NFT, FRT & \\
\hline Parsley & Petroselinum crispum & $6.0-7.0$ & $15-25$ & MBT, NFT, FRT & \\
\hline Water spinach & Ipomea aquatic & $5.6-7.3$ & $27.5-28.8$ & - & Endut et al. [10] \\
\hline Mint & Mentha arvensis $L$ & $6.1-7.12$ & $26.4-28.9$ & FRT & Wahap et al. [57] \\
\hline Pak choi & Brassica rapa L. chinensis & $6.7-7.2$ & $25-30$ & FRT & Wongkiew et al., [60] \\
\hline Chieve & Allium schoenoprasum L & $6.6-7.0$ & $23-28$ & FRT & Wongkiew et al. [59] \\
\hline Okra & Abelmoschus esculentus & $7.0-8.5$ & $29-35$ & FRT & Salam et al. [48] \\
\hline Aubergine & Solanum melongena & $7.0-8.0$ & - & MBT & Graber and Junge [17] \\
\hline Water celery & Oenanthe javanica & $6.8-7.2$ & $24 \pm 0.5$ & FRT & Paudel [41] \\
\hline
\end{tabular}

Data source except Somerville et al. [53] is non-generalized experimental set-up values. Values in parentheses refer the optimal temperature range

$M B T$ media-based technique, NFT nutrient film technique, FRT floating raft technique, respectively

${ }^{a}$ These values show the day and night temperature range

\subsubsection{Bacteria}

Bacteria, the third candidate in the aquaponics after fish and plant, culture in biofilter that generally located in between clarifier and grow beds. They convert fish wastes into consumable nutrients for plants by a process called nitrification. Nitrification in aquaponics is facilitated by the bacterial community in two intermediate and sequential steps. First, TAN is oxidized to nitrite $\left(\mathrm{NO}_{2}{ }^{-}\right)$by ammonia-oxidizing archaea (AOA) and then ammonia-oxidizing bacteria (AOB) (e.g., Nitrosomonas, Nitrosococcus, Nitrosospira, Nitrosolobus, Nitrosovibrio sp., etc.). However, $\mathrm{AOA}$ oxidizes ammonia in low $\mathrm{NH}_{4}{ }^{+}$concentration and is rare in aquaponic systems. Sequentially $\mathrm{NO}_{2}^{-}$is oxidized to $\mathrm{NO}_{3}^{-}$by nitrite-oxidizing bacteria (NOB), e.g., Nitrobacter, Nitrococcus, Nitrospira, Nitrospina sp. etc [59]. Schmautz et al. [52] analyzed microbial diversity in various compartments of an aquaponics system. Microbes like Fusobacteria, Proteobacteria, Firmicutes, Planctomycetes, Bacteroidetes may also be present but they have minimal or no influence in the aquaponic performance.

\subsection{System components}

\subsubsection{Fish tank}

Fish tank is a container to rear fish in aquaponic systems. Size of the tank should be sufficient enough to supply feed and hold the estimated fish quantity in the system. Generally, the effluent drain is located at the center of the tank. It is better to adopt a circular tank, as water approaches the center with low turbulence, and facilitates efficient removal of effluents. Also, radius to height ratio is of 3:1-4:1 which allows centripetal forces to bring the solid toward the central drain. Fiber glass is commonly used for fish tanks, but owing to its high price, high-density polyethylene (HDPE) and ethylene propylene diene monomer (EPDM) liners are also used in commercial scale systems [38]. Size of fish tank is also governed by hydrobed area and plant density to be maintained in the system. 


\subsubsection{Biofilter}

Biofilter is a device used to control the concentration of toxic nitrogenous wastes from fish tank in a closed system. Basically, it is a media with large surface area per unit volume so that many bacteria can grow and adhere over the large surface. Ammonia released from fish metabolism is toxic to fish even in low concentration of $1 \mathrm{mg} / \mathrm{L}$ [38]. Higher stocking density of fish can cause quick rise in ammonia concentrations. Biofiltration mainly involves nitrosomonas and nitrobacter to convert ammonia into nitrite, and nitrite into nitrate by simultaneous process of nitrification and denitrification, respectively [43]. Thus, the resulting $\mathrm{NO}_{3}{ }^{-}$concentration $(<300 \mathrm{mg} / \mathrm{L}$ ) is less toxic to fish than $\mathrm{NH}_{4}{ }^{+}$and $\mathrm{NO}_{2}{ }^{-}$[59]. Common biofilter media includes sand, gravel, shell, plastic media, sponge, and bioballs etc. [38, 39, 43]. Filter media with higher surface area is highly preferable.

\subsubsection{Plant grow bed}

Plant grow bed is basically a container for the growth of plant in aquaponic systems. The design and function of the grow bed in aquaponic systems is no different than that of the hydroponic system [38]. Growing bed provides static, continuously flowing or aerated nutrient solution for the plant roots in suspension [4]. Although, being a hydroponic subsystem, growing bed does not involve soil, it contains pipes, raft and media materials like gravels, sponges. In this component, plants after germination are transferred to grow until harvesting time.

\section{Types of aquaponics}

\subsection{Nutrient film technique}

Nutrient film technique (NFT) is a type of aquaponics in which the plants are placed in small plastic cups with their roots submerged in the water through which they can absorb nutrients (Fig. 2). Source of nutrient rich water is either pumped through small enclosed gutters contained synthetic nutrient solution or other source such as aquaculture tank. A thin film of water is continuously supplied to the channel through which oxygen and nutrients are provided to the plants. This system, generally used to grow green leafy vegetables [2] is easy to operate, clean and maintain. NFT generally utilizes plastic pipes for nutrient supply as they are light weight and also enables the adjustment of pipe as per plant density according to the growth stage of the crop. Owing to lack of enough area for the flourishing of bacterial community in such small pipes, a separate biofilter component is essential in such systems [38]. Nutrient film technique requires continuous flow of nutrient to the plants thus it is vulnerable to pump failures. Such disruption in the water flow results in the wilting of plants [43]. Lennard and Leonard [27] found that NFT hydroponic system is less efficient at removing nutrient from fish culture water and producing plant biomass than other two systems(FRT and MB). Nutrient uptake in NFT is low due to smaller root-water contact area [16]. NFT provides high oxygen to plant roots but is unfit for culturing of large rooted plants that is mainly due to potential blockage of nutrient supply pipes.

\subsection{Floating raft technique}

Floating raft technique (FRT) consists of floating polystyrene boards/rafts (Fig. 3) allowing the roots to suspend in the water. This hydroponic subsystem is suitable for both leafy vegetables as well as large plants like tomato or okra [43]. In this system, the raft floats on top of the large tank, so that there is no clogging effect [59]. FRT uses large volumes of water in hydroponic subsystem, which also increases the buffer capacity against ammonia and reserves nutrients for longer periods of time, even during pump disruption or reduction in fish biomass [38]. On other hand, heavy water requirement demands pumps operation and higher cost of energy. FRT may be more susceptible to breeding of mosquito larvae due to large water area. Moreover, this system becomes unsuitable for roof-top aquaponics, since it has heavy components [16]. A major demerit of FRT is that the roots in the raft could be exposed to harmful organisms associated with the aquaculture system. Also, if the fishes have access to the hydroponic system, they
Fig. 2 Schematic of generic design of NFT aquaponic system

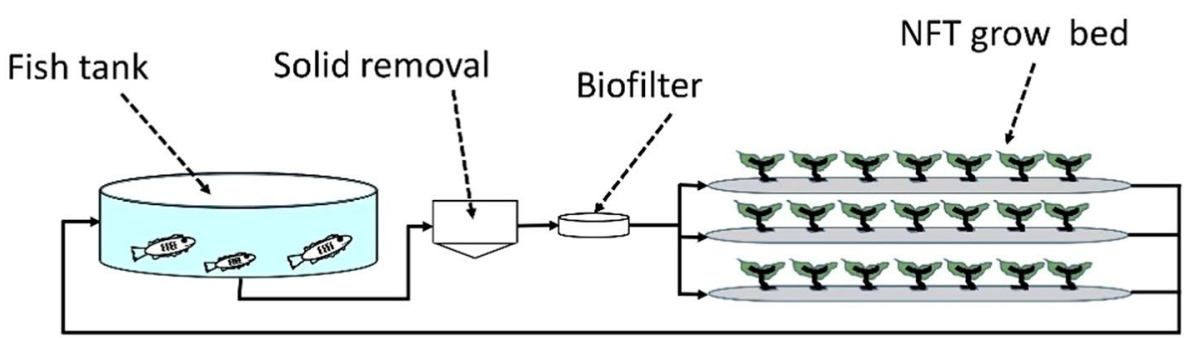

Return line 
Fig. 3 Schematic of generic design of FRT aquaponic system

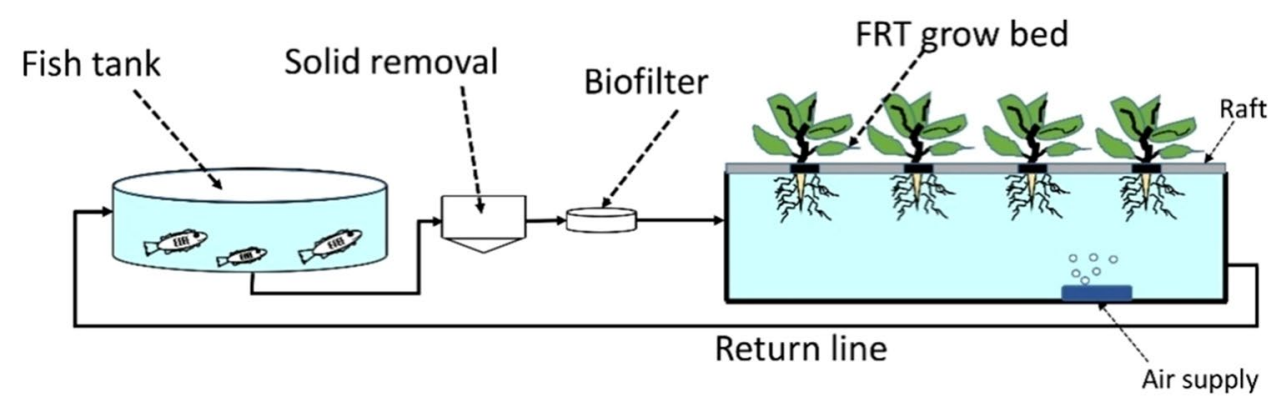

will consume the plant roots and thus can cause significant hindrance on the plant growth [43]. FRT, however, has some cons is largely used for commercial scale due to additional benefits.

\subsection{Media-bed technique}

Media-bed technique (MBT) is the simplest form of aquaponics, which contains a large container with growth media (Fig. 4). For small systems, gravel is a common hydroponic media. However due to several problems like clogging, anaerobic zone formation, sturdy infrastructure requirements, etc. other inorganic media such as sand, perlite, pea gravel, tuff, and clay are also used $[38,43]$. Organic hydroponic media includes sphagnum peat moss, pine bark, or coconut fiber. Media beds are suitable for leaf, fruit and root vegetables [38]. Major advantage of media-bed technique is its ability to work without biofilter [59]. Also, this system requires less management and fewer components. Nutrient uptake is also high in media filled technique [16]. Media like gravel provides calcium during nitrification for plant growth. However, accumulation of organic matters in the media bed causes formation of anaerobic zones affecting plant roots. Planting in hard media is also difficult as compared to other aquaponic systems. Continuous flow of water to the media is required in the system. Therefore, this system is relatively inconvenient in the case of where power supply is irregular.

\section{Factors affecting aquaponics performance}

Healthy growth of both fishes and plants depends upon water chemistry, which in turn depends on the quality of the feed, stock of fish, functioning of settling tanks, biofilters, grow beds, aeration devices, and build-up of organic materials and associated bacteria anywhere in the system. The important environmental and operational factors that affect aquaponics performance are discussed below.

\section{$5.1 \mathrm{pH}$}

The regulation of $\mathrm{pH}$ is crucial in aquaponics systems. The required $\mathrm{pH}$ value has to be maintained in order to create a balanced and stable environment for the fishes, plants and bacterial community. As the nitrification process occurs, the $\mathrm{pH}$ value declines due to the increase in concentrations of $\mathrm{H}^{+}$and $\mathrm{NO}_{3}{ }^{-}$ions. $\mathrm{pH}$ level also affects plant performance. The optimum $\mathrm{pH}$ for plant health and nutrient uptake is usually in the range of 5.5-6.5 [43]. Nitrifying bacteria, on the other hand, perform best (in terms of ammonia reduction) at $\mathrm{pH}$ levels of 7-8.5. Nitrification almost stops at $\mathrm{pH}$ below 6 [49]. For the optimum growth of fishes, $\mathrm{pH}$ requirements are usually intermediate, generally preferring $\mathrm{pH}$ of 6.5-8.5 [62]. Essential minor nutrients such as iron, manganese, copper etc. are less available to plants at a $\mathrm{pH}$ higher than 7.0, while the solubility of phosphorus, calcium, magnesium and molybdenum sharply decreases at a pH lower than 6.0 [43]. The pH of 6.5 or lower is preferred for solubility of micro nutrients [45]. Therefore, $\mathrm{pH}$ value should be adjusted so that ammonia
Fig. 4 Schematic of generic design of media-bed aquaponic system
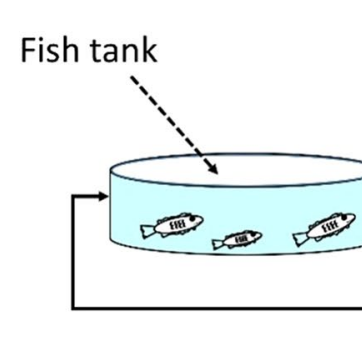

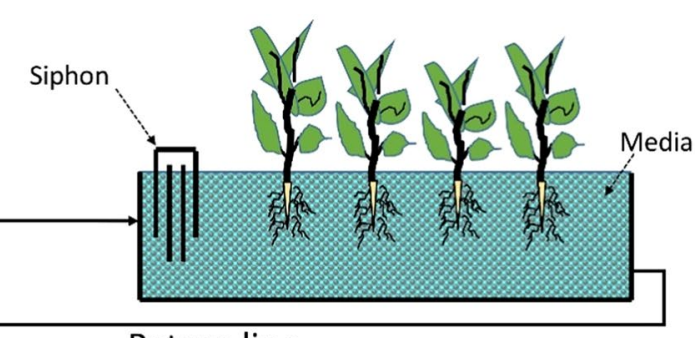

Return line 
cannot accumulate in the system. The optimal permissible value of $\mathrm{pH}$ in aquaponic systems is 6.8-7.0. Therefore, $\mathrm{pH}$ is usually maintained and is regularly monitored at a tolerable range of 6.4-7.4 in aquaponics by regular dosing of lime.

\subsection{Feed quality and feed rate}

Fish feed is the major source of nutrient input in an aquaponic system. Healthy growth of fishes and plants depend upon the quality of feed being used. Enhanced feed quality reduces fecal solid production and improves feed efficiency [62]. Poor quality of feed results in more fecal wastes which cause disturbance in the whole system, especially if there is absence of well efficient settling equipment. Also, it results in poor growth of both plants and fishes, and possibly degrades the taste quality of the food products generated [20]. Quality of fish feed is also essential for the balanced and healthy environment, and better performance of both fishes and plants. In fact, different diets are required for different growth stages of fish. Feed requirement for adult and juvenile fish are $1-3 \%$ and about $7 \%$ of their body weight, respectively [58]. Diets for pre-adult fish are richer in crude protein (40-50\%) for their growth meanwhile feed with crude protein (30-40\%) might be sufficient for mature adult fish [20]. During the mature growth phase of plants, they need more nutrients and hence higher feeding rate requires to be supplied. Graber and Junge [17] observed the positive influence of feeding load on nutrient availability to plants. Hence, in addition to the quality of feed, feeding rate also plays a crucial role in the aquaponics which is also influenced by plant culture method.

\subsection{Nutrient concentration}

In aquaponics, nutrients necessary for plants are delivered via aquaculture wastewater. Fish excreta contain sufficient levels of ammonia, nitrate, nitrite, phosphorus, potassium, and other micronutrients for the hydroponic plants [8]. Nutrient requirements in aquaponic systems vary according to the growth stage of plants. For instance, nitrate requirement is more during the vegetative growth of leafy plants while lower concentrations are appropriate during ripening of fruiting vegetables [56]. To stabilize an aquaponic system, higher nutrient concentration is not desirable as most fish can normally tolerate nitrate $\left(\mathrm{NO}_{3}{ }^{-}\right)$levels up to $200 \mathrm{mg} / \mathrm{L}$ while concentrations above $300 \mathrm{mg} / \mathrm{L}$ are toxic $[30,58]$. To overcome this difficulty of nutrient balance between fishes and plants, supplement nutrients like chelated iron, calcium hydroxide and potassium hydroxide can be externally provided to supply other important nutrients like iron, calcium, potassium, etc. [43].
Hence, nutrient concentration will be another key player for nitrogen recovery by plants.

\subsection{Temperature}

The aquaponics performance is mainly governed by growth temperature for both fishes and plants. Therefore, an optimum temperature is also required to maintain for creating healthy environment in the system [14]. Temperature selection depends on the species of plants and fish used in the system. Also, upraised aquaponic temperature increases metabolism, respiration and oxygen demand of fish [62]. An optimum temperature for Tilapia (Oreochromis niloticus) growth is $25-30^{\circ} \mathrm{C}$; for most lettuce species is $17-25^{\circ} \mathrm{C}$; and for Carp (Cyprinus carpio) is $20-26^{\circ} \mathrm{C}$ [20]. To maintain the optimum water temperature heating system requires during the winter while year-round cooling in tropical zones. General water temperature for hydroponic plants is $16-30{ }^{\circ} \mathrm{C}\left(21-23^{\circ} \mathrm{C}\right.$ optimum). Temperature adoptability of warm water and cold water fish varies between $22-32^{\circ} \mathrm{C}$ and $10-18{ }^{\circ} \mathrm{C}$, respectively $[49,62]$, whereas biofilter performance thrives well in temperatures between 25 to $30^{\circ} \mathrm{C}$ [49]. Thus, temperature plays vital role for nitrogen transformation which ultimately affects potential nitrogen recovery of the system.

\subsection{Dissolved oxygen (DO)}

In aquaponic system, it is also important to maintain the DO levels in culture water for the optimal growth of both plants and fishes. Fishes breathe the dissolved oxygen through cellular respiration and hydroponic plants undergo intense root respiration to extract the dissolved oxygen from the available water [14]. In low DO concentrations, energy conversion ability of fishes is reduced, thus resulting in decline in growth rate and feed efficiency [62]. Deficiency of dissolved oxygen impacts the plant growth as nutrient uptake decreases due to the reduction in water absorption which results in loss of cell tissue from roots. Also, deduction in DO level enhances growth of pathogens. Cold water fishes require more DO concentration (6.5 ppm) than that of warm water fishes (5 ppm) [49]. Optimum DO level for optimal growth of biomass should be maintained which is usually greater than $5 \mathrm{ppm}$ [45]. DO level is a key factor that affects nitrogen transformation and potential nitrogen recovery via aquaponic system too.

\subsection{Hydraulic loading rate}

Liquid flow rate per unit surface area of grow bed is termed as hydraulic loading rate (HLR). Favorable time of contact between nutrients, microbes present in the aqueous phase, and plant roots is mainly guided by the value 
of HLR [29]. Low HLR results in deficiency of oxygen inducing denitrification and loss of nitrogen from the aqueous phase. On the other hand, high HLR reduces the contact time between the recirculating water and the plant roots, and washes out the microbes and sediment attached to the plant roots and biofilter media [10]. Optimum HLR under different environmental conditions in aquaponics has not been investigated yet. Therefore, it is also required to examine for optimal growth of aquaponic biomasses (fish and plant). Overall, HLR-a key design parametercan also affect fate of nitrogen including potential nitrogen recovery via aquaponic system.

\section{Discussion}

\subsection{Nitrogen transformation in Aquaponic system}

Nitrogen is regarded as the building block for all life forms. Nitrogen transformations are the key biochemical processes in an aquaponic system (Fig. 5). Fish feed, which is rich in protein helps in the cellular growth and energy assimilation, hence providing free energy for metabolism and heat losses [26]. Part of the fish feed remains unconsumed. The consumed food is partly converted into fish biomass, partly defecated, and partly excreted as un-ionized ammonia through gills. The sum of un-ionized ammonia $\left(\mathrm{NH}_{3}\right)$ and ionized ammonium $\left(\mathrm{NH}_{4}^{+}\right)$in the aqueous phase is termed as total ammonia nitrogen (TAN) [22].

In an aquaponic system, nitrification is the main phenomena for converting $\mathrm{NH}_{4}{ }^{+}$to $\mathrm{NO}_{3}{ }^{-}$. There are basically two steps involved in this conversion: firstly, TAN is oxidized into nitrite $\left(\mathrm{NO}_{2}^{-}\right)$by ammonia-oxidizing bacteria (AOB) (e.g., Nitrosomonas, Nitrosococcus, Nitrosovibrio sp., Nitrosolobus etc) and then the $\mathrm{NO}_{2}{ }^{-}$is changed into nitrate $\left(\mathrm{NO}_{3}{ }^{-}\right)$by nitrite-oxidizing bacteria (NOB) (e.g., Nitrobacter, Nitrospira etc) [9]. In an aquaponic system, $\mathrm{NO}_{3}{ }^{-}$concentration limit is about $300 \mathrm{mgN} / \mathrm{L}$, above which is harmful to fish [30]. However, studies show that TAN and $\mathrm{NO}_{2}{ }^{-}$concentrations should be kept at comparatively low levels in order to maintain the amount of $\mathrm{NO}_{3}{ }^{-}$in the system [5]. The residual TAN and unused feed are hence filtrated in biofilter, and solids are separated.

Thus, formed $\mathrm{NO}_{3}{ }^{-}$is consumed by plants for their growth which is referred as nitrogen uptake. Photosynthesis takes place in the plants with the help of water and minerals in the roots transported via xylem. $\mathrm{NO}_{3}{ }^{-}$is converted into organic nitrogen with the help of many enzymes such as nitrate reductase (NR), nitrite reductase $(\mathrm{NiR})$, glutamine synthetase (GS), glutamate synthase (glutamine: 2-oxyglutarate aminotransferase, or GOGAT), glutamate dehydrogenase (GDH), aspartate aminotransferase (Asp-AT) and asparagine synthetase (AS) [54]. During the process of translocation and assimilation, influx and efflux of inorganic nitrogen also takes place between the roots and the recirculating water. In suitable environmental conditions, plant roots are vital in regulation of nitrogen in aquaponics via nitrification and denitrification process under flourishing microbial activity. In fact, biofilm of exopolymeric substances (EPS) formed on root mats mainly contributes on nitrification and denitrification processes [41].

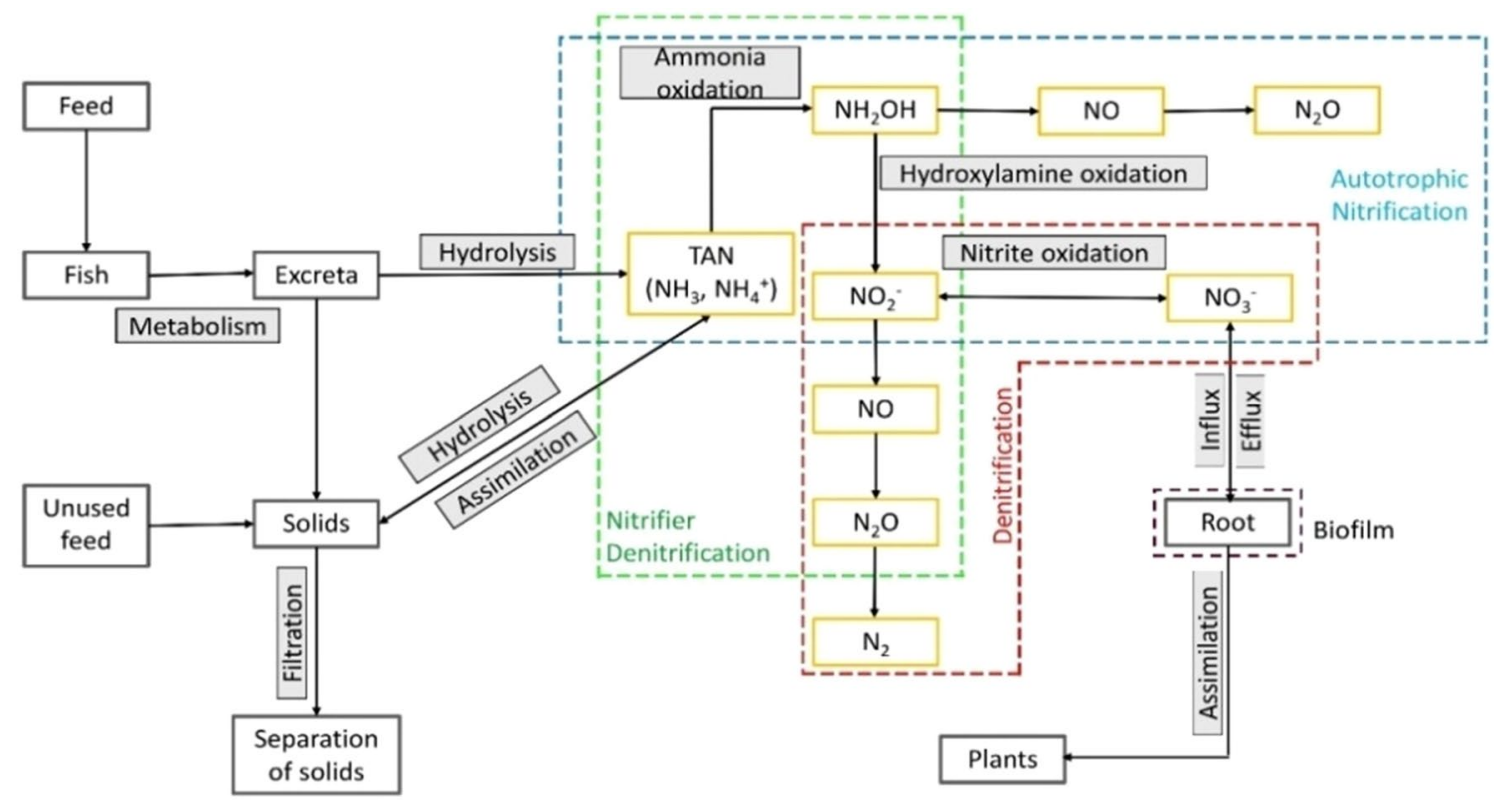

Fig. 5 Possible nitrogen transformation pathways in aquaponics 
Nitrogen loss occurs in the system mainly due to some reasons: one of them is denitrification which aids to nitrogen loss of about 25-60\% [21]. Nitrogen use efficiency (NUE) is decreased due to the losses from the system [58]. Denitrifiers transform $\mathrm{NO}_{3}{ }^{-}$to $\mathrm{NO}_{2}{ }^{-}$, nitric oxide (NO), nitrous oxide $\left(\mathrm{N}_{2} \mathrm{O}\right)$ and finally to nitrogen gas $\left(\mathrm{N}_{2}\right)$ under anoxic condition (low dissolved oxygen conditions). This is also carried out by nitrifier denitrification process [61]. Various archaea, facultative heterotrophic bacteria such as Achromobacter, Aerobacter, Acinetobacter, Bacillus, Brevibacterium, Flavabacterium, Pseudomonas, Protus and Microoccus $s p$. help in this process. Other losses occur via assimilation of heterotropic bacteria, anaerobic ammonium oxidation and ammonia volatilization $[58,60]$. In fact, nitrogen recovery potential by hydroponic plants mainly depends on fate of nitrogen and its species concentration too. And, critical analysis of isotopic signature or abundance of nitrogen isotopes-however, little study has begun to investigate it-in aquaponics can help find the exact pathway of fate of nitrogen in the system.

\subsection{Potential nitrogen recovery from aquaponics}

Aquaculture solely is an unsustainable practice of production, because large amount of nitrogen is lost as effluents. In order to minimize that loss, aquaculture can be combined with hydroponic subsystem. For estimating numeric values of nitrogen recovery, nitrogen loss scenario via aquaculture and potential nitrogen utilization/recovery by plants in aquaponics was considered. Aquaculture production data was exploited from Food and Agriculture Organization [11] for the years, 1980-2016. Then, the amount of waste nitrogen from aquaculture in aqueous phase can be estimated using Eq. 1 [22].
$N_{\text {aqueous }}=0.77 \times N_{\text {input }}$

where $N_{\text {aqueous }}$ is the quantity of nitrogen being rejected to water after assimilation by fish; $N_{\text {input }}$ is the total nitrogen introduced in the system as fish feed. Equation (1) is significant in illustrating the potential nitrogen loss from existing aquaculture. The study can be further expanded based on fish production where $N_{\text {input }}$ in the system can be estimated using Eq. 2.

$W_{\text {fish }}=8.18 \times N_{\text {input }}$

where $W_{\text {fish }}$ is amount of fish production from aquaculture; $N_{\text {input }}$ is the total nitrogen introduced in the system as fish feed. Overall development of this equation depends upon the assumption that fish feed is the only source of nitrogen, and that all of the fish feeds are ingested by the fishes (i.e., there is no any residual feed). Potential $N_{\text {aqueous }}$ was estimated based on the predicted data for the years 2020 and 2030 [40]. As the aquaculture production was increased over the years, the estimated annual variation of aqueous phase nitrogen (potential waste) was also significantly increased over the years (Fig. 6).

Nitrogen effluent from aquaculture can be utilized for vegetable production in recirculating system. Nitrogen input is distributed in various components of aquaponic system with partial loss to surrounding environment. Nitrogen distribution can be well understood by the study of Wongkiew et al. [59]: lab experiment on floating raft aquaponic system revealed the nitrogen recovery by tomato and chive to be $44 \%$ and $1.7 \%$ of total nitrogen input, respectively; similarly nitrogen recovery by lettuce and Pak Choi was found to be about $20 \%$. Considering fish tank as an isolated system (i.e., nitrogen effluent from both aquaculture and aquaponic system remains
Fig. 6 Estimated annual variation of aqueous phase nitrogen in Nepalese aquaculture

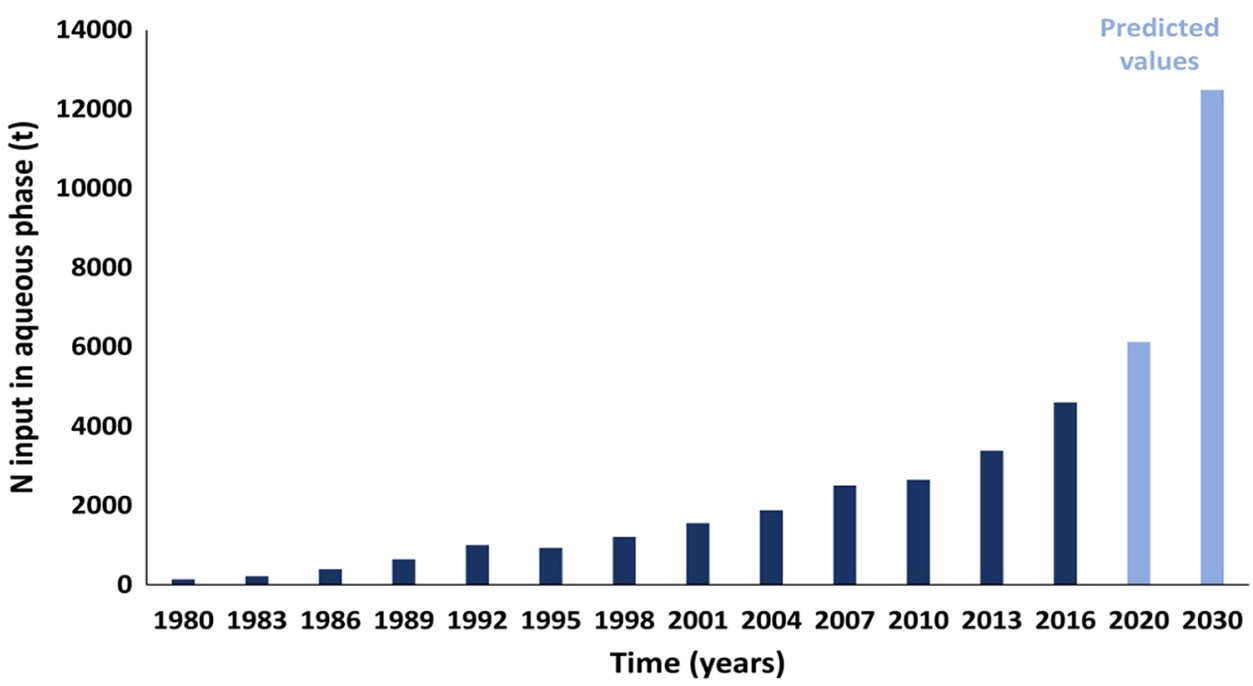

SN Applied Sciences A SPRINGER NATURE journa 
equal), and nitrogen effluent as the only source of nitrogen for plants tentative, the quantification of nitrogen recovery can be developed based on the total nitrogen input in aquaculture with corresponding nitrogen utilization by plants in aquaponics.

It can be estimated that Nepal has the potential to recover as high nitrogen as $3509 \mathrm{t}$ and $7157 \mathrm{t}$ through aquaponic aquaculture for the year 2020 and 2030, respectively (Table 2 ). Aquaponic system can be practiced as a measure of sustainable fish and plant production in future. Current soil-based agriculture practice in Nepal uses excessive chemical fertilizer that increases an alarming rate of $882.43 \mathrm{t}$ per year, urea being most widely consumed fertilizer with NPK (Nitrogen-Phosphorus-Potassium) ratio of 46-0-0 [37]. Considered this fact, aquaponic aquaculture practice could be the organic substitute of urea fertilizer. Nitrogen recovery from aquaponics is equivalent to $7628 \mathrm{t}$ and $15558 \mathrm{t}$ of urea fertilizers for year 2020 and 2030, respectively (Table 2). Hence, aquaponics can emerge as suitable organic vegetable production with independent nutrient supply over soil demanding farming which requires chemical fertilizer supplement.

On the global scenario, $\mathrm{N}$ loss from aquaculture is considerably high. China is a major source of aquaculture production, and resultantly major source of $\mathrm{N}_{2} \mathrm{O}-\mathrm{N}$ emission from fishery sector. Nitrogen loss of $7.52 \times 10^{6} \mathrm{t}$ was estimated across the world for year 2016 (Table 3). In order to meet environment and production sustainability, this number has to be minimized. Developing countries like Nigeria, Bangladesh, India, and Indonesia struggling for nutritional security have not been able to utilize/manage the existing nitrogen loss as a resource. Aquaponics is a potential source of waste stream of nitrogen utilization for the production of organic vegetables and plant species. Besides the existing fish production, additional plants production can be achieved which could be supportive for meeting global food demand and nutritional security.

The estimation of nitrogen loss and its potential recovery are theoretically approached in order to perceive the necessity of nitrogen effluent management. The data are pertinent mathematically, but the exact figures cannot be
Table 2 Estimation of potential nitrogen recovery from aquaponics in Nepal

\begin{tabular}{|c|c|c|c|c|c|c|}
\hline \multirow[t]{2}{*}{ Year } & \multirow[t]{2}{*}{$\begin{array}{l}\text { Aquaculture } \\
\text { production }(t)^{a}\end{array}$} & \multirow[t]{2}{*}{$\begin{array}{l}\text { Estimated } \mathrm{N} \text { input in } \\
\text { water bodies }(\mathrm{t})\end{array}$} & \multicolumn{4}{|c|}{$\begin{array}{l}\text { Estimated } N \text { recovery via different plant species } \\
(t)^{b}\end{array}$} \\
\hline & & & Tomato & Pak choi & Lettuce & Chieve \\
\hline 2020 & 65,200 & 6122.41 & 3508.55 & 1594.79 & 1594.79 & 135.55 \\
\hline 2030 & 133,000 & $12,488.98$ & 7157.00 & 3253.18 & 3253.18 & 276.52 \\
\hline
\end{tabular}

${ }^{a}$ Data source: Paudel et al. [40], 't' is weight unit (tonnes)

${ }^{b}$ Estimated nitrogen recovery using $\mathrm{N}$ content of plant species in FRT

Table 3 Global nitrogen loss and its potential recovery scenarios via aquaponics from aquaculture practice, 2016

\begin{tabular}{llcccc}
\hline Continent/region & Country & $\begin{array}{l}\text { Aquaculture fish pro- } \\
\text { duction }\left(\times 10^{3}, \mathrm{t}\right)\end{array}$ & $\begin{array}{l}\text { Estimated N release in } \\
\text { water bodies }\left(\times 10^{3}, \mathrm{t}\right)\end{array}$ & $\begin{array}{l}\text { Potential } \mathrm{N}_{2} \mathrm{O}-\mathrm{N} \\
\text { emission }(\mathrm{t})\end{array}$ & $\begin{array}{l}\text { Estimated } \mathrm{N} \text { recovery } \\
\text { from aquaponics }\left(\times 10^{3},\right. \\
\mathrm{t})\end{array}$ \\
\hline Asia & China & 49,244 & 4624.11 & $83,222.36$ & 2649.92 \\
& India & 5700 & 535.24 & 9633 & 306.72 \\
& Indonesia & 4950 & 464.81 & 8365.5 & 266.36 \\
& Vietnam & 3625 & 340.39 & 6126.25 & 195.06 \\
Europe & Bangladesh & 2204 & 206.96 & 3724.76 & 118.60 \\
& Norway & 1326 & 124.51 & 2240.94 & 71.35 \\
Africa & EU-28 & 1292 & 121.32 & 2183.48 & 69.52 \\
& Egypt & 1371 & 128.73 & 2316.99 & 73.77 \\
America & Nigeria & 307 & 28.82 & 518.83 & 16.52 \\
Oceania & Chile & 1035 & 97.18 & 1749.15 & 55.69 \\
Global & - & 210 & 19.71 & 354.9 & 11.30 \\
\hline
\end{tabular}

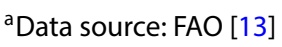

${ }^{\mathrm{b}}$ Estimated $\mathrm{N}_{2} \mathrm{O}-\mathrm{N}$ emission using emission factor $1.69 \mathrm{~g} / \mathrm{kg}$ fish

${ }^{\mathrm{c}}$ Estimated $\mathrm{N}$ recovery from aquaponics using $44 \% \mathrm{~N}$ content of tomato in FRT 
established with ample confidence. Fish biomass is greatly affected by the parameters like $\mathrm{pH}, \mathrm{DO}$, water exchange, etc. of the fish tank. Plant species also alter the fish biomass under different environmental conditions. Higher feed consumption and higher fish biomass has been observed in tomato-based aquaponics due to better water quality [21], thereby, indicating to the possibility of less fish biomass if there is non-recirculation and accumulation of $\mathrm{NO}_{3}{ }^{-}$. Nitrogen content of fish in aquaponics was found in between 21.0 and $27.9 \%$ of the total nitrogen input through fish feeds [59]; hence, the representative value of $23.22 \%$ was used to calculate the nitrogen effluent, and consequently to estimate the potential recovery. Nitrogen content of $23.22 \%$ had been developed on the basis of study over 80 different kinds of fish species, of which only 60 different species of fish are reared in Nepal [40]. Amount of nitrogen in plant body was found to be $44 \%$ (of the nitrogen input in the system through fish feeds) for tomato, $20 \%$ for pak-choi and lettuce, $1.97 \%$ for chive, which are subject to variations with change in experimental conditions. Aquaponics is a bio-integrated and multiple component system in which change in parameters and conditions of individual component noticeably affect the output of system. Such parameters include $\mathrm{pH}$ and water temperature that should be maintained in certain range as mentioned above in Sect. 5. For the successful operation of the aquaponic system, the balance of feed rate ratio is one of the guiding factors, which depends on the species of plants grown as well. Fruiting vegetables require about one third more nutrients than leafy greens to support flowers and fruit development [53]. Nitrogen content in tomato and pak-choi was found as low as $17 \%$ and $15 \%$, respectively, under different experimental conditions [21]. Their experimental set-up may not accurately replicate the value for commercial production. However, tentative data reinforce the necessity of alternative approaches to utilize nitrogen effluent of aquaculture and to develop sustainable production practices.

Likewise, fish biomass (wet body) on average contains $17.22 \pm \mathrm{v} 2.97 \%$ proteins, and nitrogen content of many proteins is $16 \%$. Hence, theoretically, $2.84 \%$ of nitrogen is present in fish, i.e., for one tonne of the fish to be harvested; about $28.4 \mathrm{~kg}$ of nitrogen feed can be recovered. Also, studies have documented that about $23.22 \pm 6.88 \%$ of nitrogen consumed by fish is converted to fish biomass. Hence, every metric tonne of fish consumes a total of $122.3 \mathrm{~kg}$ of nitrogen. On the assumption that all the feed is consumed by fish (no residual feed), $93.9 \mathrm{~kg}$ is produced as nitrogenous waste in production pond $[22,40]$. As ammonia rich water in aquaculture undergoes nitrification and denitrification that results in emitting $\mathrm{N}_{2} \mathrm{O}$ in the atmospheric. The average $\mathrm{N}_{2} \mathrm{O}$ emission factor of aquaculture system is $1.69 \mathrm{~g} \mathrm{~N}_{2} \mathrm{O}-\mathrm{N} / \mathrm{kg}$ fish [22]. Based on the emission factor, Paudel et al. [40] estimated potential nitrous oxide emission from aquaculture in Nepal to be $2.25 \times 10^{2} \mathrm{t} \mathrm{N}_{2} \mathrm{O}-\partial \mathrm{N}$ by 2030 .

$\mathrm{N}_{2} \mathrm{O}$ is a potential global warming gas and also is the most dominant ozone layer depleting gas in the twenty first century [46]. Atmospheric traces of $\mathrm{N}_{2} \mathrm{O}$ are pivotal in regulating stratospheric ozone layer, contributing to greenhouse phenomenon and resulting acid rain [3]. We can approach aquaponics as an alternative to existing aquaculture practices: nitrogen uptake by plants can reduce the nitrogen content of aquaculture wastewater thereby resulting in reduction of potential nitrous oxide emission. The aquaponics is not an absolute solution of $\mathrm{N}_{2} \mathrm{O}$ emission; however, Paudel [41] observed $17 \%$ reduction in $\mathrm{N}_{2} \mathrm{O}$ emission from aquaponics with water celery. Under individual review, nitrogen loss $\left(\mathrm{N}\right.$ and $\left.\mathrm{N}_{2} \mathrm{O}\right)$ does occur from aquaponic system as well. Study of $\mathrm{Hu}$ et al. [21] found the $\mathrm{N}_{2} \mathrm{O}$ emission, $1.5 \%$ and $1.9 \%$ of total $\mathrm{N}$ input from tomato and pak choi-based floating raft method, respectively. However, these values further vary with rate of nitrification and denitrification under changes in environmental and operational parameters like $\mathrm{pH}$, $\mathrm{DO}$, and temperature. Past study reported that there are lower concentrations of $\mathrm{NH}_{4}{ }^{-}, \mathrm{NO}_{2}{ }^{-}$and $\mathrm{NO}_{3}{ }^{-}$at aqueous phase in aquaponics as compared to aquaculture [40]. As the concentration of $\mathrm{NO}_{3}{ }^{-}$is high compared to $\mathrm{NH}_{4}{ }^{-}$and $\mathrm{NO}_{2}{ }^{-}$in aquaponics [58], which is likely a dominant source of nitrogen for plants, and its utilization depends upon concentration, growing stages, and plant genetic factors [59]. The reduction in $\mathrm{NO}_{3}{ }^{-}$concentration through plant uptake likely leads to lower $\mathrm{N}_{2} \mathrm{O}$ emission from aquaponics over conventional aquaculture practices, since denitrification of $\mathrm{NO}_{3}{ }^{-}$in anoxic conditions is a possible pathway to $\mathrm{N}_{2} \mathrm{O}$ emission [22]; however, measurement of reduction factor for $\mathrm{N}_{2} \mathrm{O}$ emission is difficult due to uncertain pathways of nitrogen transformation though few study was investigated in this field.

\subsection{Current status and prospects of aquaponics}

The primal idea of aquaponics dates back to 1000 A.D. when plants were grown on rafts, while the term aquaponics was coined in 1970s. In recent times, various research works have been investigated over the last three decades across the globe. However, in Nepal, aquaponics is at its rudimentary stage of development with only few domestic practices in cities like Syangja, Surkhet, and Kathmandu. "Hope Nepal Bioponics", an agri-business private company, has been pioneering aquaponic food production in Nepal since 2006 while Scott Wilson (SW) Nepal (private company) is also working on flourishing aquaponics in Nepal. The Rotary Club of Patan, Nepal and the Rotary Club of Brussels has run an aquaponics unit which is funded by 
Rotary International and is supported by The Social Enterprise, Aquaponics [31]. Experimental evaluation of Gyawali et al. [19] at Institute of Agriculture and Animal Science, Tribhuvan University, Pakhihawa, Nepal on Outdoor Barrel Aquaponics can be taken as major significant step toward advancement in Aquaponics in Nepal [19].

Nepal has been working on aquaponics in a comparatively slower pace, but a positive growth can be expected in future because of its benefits and adoptive suitability. Food and nutritional security and poor diet diversity has been a critical issue for Nepal in present scenario. Nepal is unlikely to achieve daily standard requirement of $30 \mathrm{~g}$ of fish or meat protein any time soon [18]. On average, national dietary energy intake is $2536 \mathrm{kcal}$ per capita per day which is higher than minimum average requirement of $2220 \mathrm{kcal}$ set by Government of Nepal. On the other side, around $38 \%$ of people are found with food energy deficient [6]. Inadequate fruit and vegetable consumption are the major reason for nutritional disorders such as lack of iron and vitamin A [12] which is found in fish in the form of retinol and dehydroretinol isomers [18]. Vegetables are also rich in vitamin A, vitamin C, iron, zinc, etc. [25]. In the existing Nepalese nutritional scenario, aquaponics can be a suitable source for both fish meat and vegetables to achieve national food and nutritional security.

Urban agriculture requires specific control measures and technologies different to that of rural agriculture. Rapid urbanization and land transformations are continuously reducing arable land; therefore roof top aquaponics can be a sustainable urban start up in the cities like Kathmandu. Junge and Graber [23] demonstrated that feasible production practice, market acceptance, and performance for possible commercialization of aquaponics in urban city with reduced transport dependency and market hikes enhanced the public health in vicinity. Aquaponics can also contribute in organic production which can avail for additional nutritional supplement since they possess greater nutritional value and lower toxic chemicals [7]. Generally, organic certified rock potassium sulfate containing $50 \% \mathrm{~K}_{2} \mathrm{O}$ and kelp powder may be added as adequate potassium supplement [51]. Organic product finds premium market in urban cities of Nepal. A case study of Aryal et al. [1] revealed that around $58 \%$ of people in their study are willing to go 6-20\% price premium to get organic food indicating sufficient and feasible market for organic food products.

Furthermore, aquaponics: (1) can be substantial in economic development and utilization of unemployed manpower and land area [28]; (2) can act as synergistic system, thus reducing the shortcomings of individual units; and (3) helps reduce water use due to its inherent recirculating nature utilizing waste nutrients [55]. Aquaponics requires only about $10 \%$ of the water needed to grow the same plant in soil-based agriculture. Thus, it can be advantageous for countries like Nepal where scarcity of water has continually hampered the production of soil-based agriculture [38]. In addition, it is a proven technology for high nitrogenous waste remediation with simultaneous production of high-quality fishes and vegetables. Past studies have demonstrated that aquaponics has higher production performance over traditional soil-based farming. Experiment by Rakocy et al. $[42,44]$ reported that the yield of basil (1.8-2.0 vs. 0.6$) \mathrm{kg} / \mathrm{m}^{2}$ and okra (2.67-2.87 vs. 0.15$) \mathrm{kg} / \mathrm{m}^{2}$ in aquaponics are three times higher compared to field production. McMurtry et al. [32] and Resh [47] in their studies have also found the higher yield of lettuce and cucumber, respectively, in soilless system over soil farming. Thus, soilless growing system exhibits good potential for an effective food production source over existing system of soil-based production.

Aquaponics is further easier than in-ground cultivation as it reduces work-loads since no plowing; tilling, mulching or weeding is required. Also, monoculture can also be continually practiced in aquaponics which is not possible in soil-based agriculture because soil becomes tired, loses its fertility and starts to be diseased. Overall, aquaponics is a lucrative modern technology with high commercialization possibility in Nepal. Further advancement and expansion of aquaponics with a sustainability development approach can be well expected in the near future provided that Government of Nepal (GoN) formulates supportive policy toward aquaponics.

\subsection{Challenges of aquaponics}

Aquaponics is a complex and demanding food production technology because of its integrative and multi component nature. Aquaculture and hydroponics are familiar disciplines; problems arise when two systems merges; one of them is $\mathrm{pH}$ stabilization. Symbiotic system of fish, bacteria and plant possesses very narrow range of $\mathrm{pH}(6.4-7.4)$ for optimal performance. This necessitates frequent measurement of $\mathrm{pH}$ as it normally declines daily in response to nitrification process [16]. Other operation and environmental parameters like HLR, DO, temperature, hardness, ammonia concentration etc. also requires regular monitoring and control. Moreover, an effluent from fish tank does not contain sufficient nutrients for optimum plant performance. Additional nutrients like potassium (K), calcium (C) or iron (Fe) should be supplemented in regular basis to keep up the growth. Thus, effectiveness of organically derived nutrients over readily soluble mineral fertilizers is still debatable [35]. Besides, the application of antibiotic resistance for disease management is another challenging aspect of aquaponics. Owing to the toxicity risk to fish, nitrifying bacteria, nutrient solubilizing and 
biofilm forming organism, the use of standard pesticides has been almost prohibited [15]. Hence, it is challenging to select suitable control measure compatible to the entire living organisms in the system. Other technical issues with associated challenges generally appear in short or long run in the system has already been discussed previously in Sects. 4.1-4.3.

Besides generic technical issues, developing country like Nepal faces possible challenges such as; social, economic, and educational aspects too. Aquaponics is an emerging practice and is not widely familiar in Nepal. In absence of feasibility studies and experiments with locally available fish and plant species, it could be inconvenient to establish commercial aquaponics in large scale. This system also requires skilled manpower for operation: especially to implement aquaponic farming in local scale requires excessive and rigorous training for local farming communities. Subsistence farming practice in Nepal may discourage implementing the innovative techniques in aquaculture. Also marketing strategy of Nepal is very poor, hence farmers finds themselves in questionable production conditions in absence of secured market and marketing system [24]. Aquaponics itself is a sophisticated system of farming that requires relatively huge amount of capital investment which could also be a hurdle for a developing country like Nepal.

\section{Recommendation}

Government of Nepal has prioritized fisheries and vegetable sectors in its periodic plan. However, their potential integration through aquaponics has not been given the top priority. Sustainable Development Goals (2016-2030) by the Government of Nepal aims to end hunger, achieve food security, improve nutrition and promote sustainable agriculture [36]. Also, the government has endorsed Agriculture Development Strategy (ADS) in 2015 which will accelerate agriculture sector growth [34]. We suggest aquaponics as an essential supplement for achieving the established targets by Government of Nepal. Enough resources and funds should be allocated to develop aquaponics toward its commercial success. However, feasibility of aquaponics in Nepalese context; both physically and economically on local species of fish and vegetables should be investigated for sustainable production practice. Pre-production requirements like sustainable supply of fingerlings, fish feeds, fertilizer and supplement etc. should be evaluated and necessary resources should be planned. Post-production strategies should also be developed so that farmers can sell their products in sustainable market system, especially highlighting the development of cold storage facilities, marketing infrastructure, processing facilities etc. Training facilities and educational services (formal and informal education) should be provided to local farmers in order to promote aquaponics in rural level. Community-based farming system should be encouraged to overcome the possible obstacle of capital investment. Government should provide subsidies and support in local level for this innovative production. The local and federal government along with metropolitan city, sub-metropolitan city and municipality should come up with the congenial plan and promote aquaponics to make the cities self-reliant on the production of vegetables and fishes. Nitrogen isotopic analysis remains critical to find the exact pathways of nitrogen transformation in the system.

\section{Conclusion}

Global and national potential of nitrogen loss and recovery via aquaponics was estimated. Aquaponics demonstrates high potential for nitrogen recovery from aquaculture wastewater via nitrate reduction and nitrogen assimilation into organic vegetables and plants. There are several factors that affect the performance of the system. Thus, maintaining optimal environmental and operational condition, symbiotic species can develop successful production system. The review discussed different types of aquaponic systems with their suitability, including different plants and fish species. Possible nitrogen transformation pathway in aquaponic system is also explained, however, the exact identification of nitrogen pathways requires isotopic analysis-investigation of stable isotopic signature. On theoretical perusal of global aquaculture scenario, high amount of nitrogen loss was observed. Sudden thriving of aquaponics and surpassing aquaculture practice is almost impossible. For now, the urgency is to minimize the existing environmental impacts, but in long run, the priority is nitrogen utilization for environmental and production sustainability. The paper, however, has discussed the status and prospects of aquaponics in Nepal with associated possible challenges; also has highlighted the observations that can be extrapolated to gain insights into the existing conditions of other minor developing countries like India, Bangladesh and Nigeria etc. These countries are also struggling with nutritional and food production security. Nitrogen recovery from aquaponics can be positively considered as a sustainable technology across the globe. The formulation of global policies and strategies with longterm vision for sustainability enhancement of aquaponics are essential.

Acknowledgements Authors like to acknowledge Department of Civil Engineering, Pulchowk Campus for creating an environment conducive to writing this manuscript. We are self-motivated at writing this 
manuscript and are responsible for all kind of expense during this study. Authors like to thank anonymous reviewers for their critical comments that greatly help enhance the quality of this manuscript.

\section{Compliance with ethical standards}

Conflict of interest The authors declare that they have no conflict of interest.

\section{References}

1. Aryal KP, Chaudhary P, Pandit S, Sharma G (2009) Consumers' willingness to pay for organic products: a case from Kathmandu valley. J Agric Environ 10:15-26. https://doi.org/10.3126/aej. v10i0.2126

2. Azad KN, Salam MA, Azad KN (2016) Aquaponics in Bangladesh: current status and future prospects. J Biosci Agric Res 7(2):669677. https://doi.org/10.18801/jbar.070216.79

3. Badr O, Probert SD (1993) Environmental impacts of atmospheric nitrous oxide. Appl Energy 44(3):197-231. https://doi. org/10.1016/0306-2619(93)90018-k

4. Benton JJ (2005) Hydroponics a practical guide for the soilless grower. CRC Press, Boca Raton

5. Buzby KM, Lin LS (2014) Scaling aquaponic systems: balancing plant uptake with fish output. Aquacul Eng 63:39-44. https:// doi.org/10.1016/j.aquaeng.2014.09.002

6. CBS (2013) Nepal thematic report on food security and nutrition, Nepal

7. Crinnion WJ (2010) Organic foods contain higher levels of certain nutrients, lower levels of pesticides, and may provide health benefits for the consumer. Altern Med Rev 15(1):4-12

8. Diver S, Rinehart L (2000) Aquaponics-integration of hydroponics with aquaculture. Attra

9. Ebeling JM, Timmons MB, Bisogni JJ (2006) Engineering analysis of the stoichiometry of photoautotrophic, autotrophic, and heterotrophic removal of ammonia-nitrogen in aquaculture systems. Aquaculture 257(1-4):346-358. https://doi.org/10.1016/j. aquaculture.2006.03.019

10. Endut A, Jusoh A, Ali N, Nik WW, Hassan A (2010) A study on the optimal hydraulic loading rate and plant ratios in recirculation aquaponic system. Bioresour Technol 101(5):1511-1517. https ://doi.org/10.1016/j.biortech.2009.09.040

11. FAO (2017) National aquaculture sector overview Nepal. FAO, Italy

12. FAO (2010) Nepal at a glance. www.fao.org/nepal/fao-in-nepal /nepal-at-a-glance/en/

13. FAO (2018) The state of world fisheries and aquaculture. FAO, Rome

14. Filep RM, Diaconescu S, Marin M, Bădulescu L, Nicolae CG (2016) Case study on water quality control in an aquaponic system. Curr Trends Nat Sci 5:06-09

15. Gichana ZM, Liti D, Waidbacher H, Zollitsch W, Drexler S, Waikibia J (2018) Waste management in recirculating aquaculture system through bacteria dissimilation and plant assimilation. Aquacult Int 26(6):1541-1572. https://doi.org/10.1007/s1049 9-018-0303-x

16. Goddek S, Delaide B, Mankasingh U, Ragnarsdottir KV, Jijakli H, Thorarinsdottir R (2015) Challenges of sustainable and commercial aquaponics. Sustainability 7(4):4199-4224. https://doi. org/10.3390/su7044199

17. Graber A, Junge R (2009) Aquaponic systems: nutrient recycling from fish wastewater by vegetable production. Desalination 246(1-3):147-156. https://doi.org/10.1016/j.desal.2008.03.048
18. Gurung TB (2016) Role of inland fishery and aquaculture for food and nutrition security in Nepal. Agric Food Secur 5(1):18. https://doi.org/10.1186/s40066-016-0063-7

19. Gyawali S, Chaudhary P, Chaudhary M, Gurung S, Pathak R (2019) Comparative evaluation of Broad Leaf Mustard (BLM) under different boron concentrations in outdoor barrel aquaponics at IAAS, Paklihawa. Int J Appl Sci Biotechnol 7(3):359364. https://doi.org/10.3126/ijasbt.v7i3.25698

20. HC (2013) Aquaponics Research Report, New Zealand

21. Hu Z, Lee JW, Chandran K, Kim S, Brotto AC, Khanal SK (2015) Effect of plant species on nitrogen recovery in aquaponics. Bioresour Technol 188:92-98. https://doi.org/10.1016/j.biort ech.2015.01.013

22. Hu Z, Lee JW, Chandran K, Kim S, Khanal SK (2012) Nitrous oxide $\left(\mathrm{N}_{2} \mathrm{O}\right)$ emission from aquaculture: a review. Environ Sci Technol 46(12):6470-6480. https://doi.org/10.1021/es300 $110 x$

23. Junge R, Graber A (2014) The potential of aquaponics for food production in the cities of the future. Cities of the Future, Course Material

24. Karki NP (2016) Fish farming in Nepal: trends, opportunities, and constraints. Nepal J Agric Sci 14:201-210

25. Keatinge JDH, Yang RY, Hughes JDA, Easdown WJ, Holmer R (2011) The importance of vegetables in ensuring both food and nutritional security in attainment of the Millennium Development Goals. Food Secur 3(4):491-501. https://doi.org/10.1007/ s12571-011-0150-3

26. Lekang OI (2020) Aquaculture engineering. Wiley, New York

27. Lennard WA, Leonard BV (2006) A comparison of three different hydroponic sub-systems (gravel bed, floating and nutrient film technique) in an aquaponic test system. Aquacult Int 14(6):539550. https://doi.org/10.1007/s10499-006-9053-2

28. Li C, Lee CT, Gao Y, Hashim H, Zhang X, Wu WM, Zhang Z (2018) Prospect of aquaponics for the sustainable development of food production in urban. Chem Eng Trans 63:475-480. https://doi. org/10.3303/CET1863080

29. Li XN, Song HL, Lu XW, Xie XF, Inamori Y (2009) Characteristics and mechanisms of the hydroponic bio-filter method for purification of eutrophic surface water. Ecol Eng 35(11):1574-1583. https://doi.org/10.1016/j.ecoleng.2008.12.034

30. Losordo TM, Masser MP, Rakocy J (1998) Recirculating aquaculture tank production systems: an overview of critical considerations. Texas (USA): Southern Regional Aquaculture Center, SRAC Publication

31. Mallapaty S (2012) Nepal sees potential in aquaponics. http:// www.scidevnet/global/biotechnology/news/nepal-sees-poten tial-in-aquaponics

32. McMurtry MR, Nelson PV, Sanders DC, Hodges L (1990) Sand culture of vegetables using recirculated aquacultural effluents. Appl Agric Res 5:280-284

33. Mendelson R, Dinar A (1999) Climate change, agriculture, and developing countries: does adaptation matter? The World Bank Research Observer. http://doi.org/10.1093/wbro/14.2.277

34. MoAD (2016) Agriculture Development Strategies (ADS) 20152035, Nepal

35. Nozzi V, Graber A, Schmautz Z, Mathis A, Junge R (2018) Nutrient management in aquaponics: comparison of three approaches for cultivating lettuce, mint and mushroom herb. Agronomy 8(3):27. https://doi.org/10.3390/agronomy8030027

36. NPC (2015) Sustainable Development Goals [2016-2030], Nepal

37. Pandey G, Khanal S, Pant D, Chhetri A, Basnet S (2017) An overview of fertilizer distribution scenario in Nepal: a time series analysis. Int J Res Agri Seci 4(6):2348-3997

38. Pantanella E (2018) Aquaponics production, practices and opportunities. Sustain Aquacult. https://doi.org/10.1007/9783-319-73257-2_7 
39. Paudel SR, Choi O, Khanal SK, Chandran K, Kim S, Lee JW (2015) Effects of temperature on nitrous oxide (N2O) emission from intensive aquaculture system. Sci Total Environ 518:16-23. https ://doi.org/10.1016/j.scitotenv.2015.02.076

40. Paudel SR, Luitel S, Adhikari R, Wagle A, You K (2019) Potential nitrous oxide $\left(\mathrm{N}_{2} \mathrm{O}\right)$ emission from aquaculture in Nepal. Int J Environ Stud 76(2):318-328. https://doi.org/10.1080/00207 233.2018.1560764

41. Paudel SR (2020) Nitrogen transformation in engineered aquaponics with water celery (Oenanthe javanica) and koi carp (Cyprinus carpio): effects of plant to fish biomass ratio. Aquaculture 520:734971. https://doi.org/10.1016/j.aquaculture.2020.73497 1

42. Rakocy JE, Bailey DS, Shultz RC, Thoman ES (2004) Update on tilapia and vegetable production in the UVI aquaponic system. New dimensions on farmed Tilapia. In: Proceedings of the sixth international symposium on Tilapia in Aquaculture, $p p$ $12-16$

43. Rakocy J, Masser MP, Losordo T (2016) Recirculating aquaculture tank production systems: aquaponics-integrating fish and plant culture

44. Rakocy J, Shultz RC, Bailey DS, Thoman ES (2003) Aquaponic production of tilapia and basil: comparing a batch and staggered cropping system. S Pac Soill Culture Conf SPSCC 648:63-69. https://doi.org/10.17660/actahortic.2004.648.8

45. Rakocy J (2007) Ten guidelines for aquaponic systems. Aquaponics J 46:14-17

46. Ravishankara AR, Daniel JS, Portmann RW (2009) Nitrous oxide $\left(\mathrm{N}_{2} \mathrm{O}\right)$ : the dominant ozone-depleting substance emitted in the 21 st century. Science 326(5949):123-125. https://doi. org/10.1126/science.1176985

47. Resh HM (2016) Hydroponic food production: a definitive guidebook for the advanced home gardener and the commercial hydroponic grower. CRC Press, Boca Raton

48. Salam MA, Asadujjaman M, Rahman MS (2016) Aquaponics for improving high density fish pond water quality through raft and rack vegetable production. World J Fish Mar Sci 5(3):251-256

49. Sallenave $R, 2(016)$ Important water quality parameters in aquaponics systems. NM State University, Cooperative Extension Service, College of Agricultural, Consumer and Environmental Sciences, New Mexico

50. Savci S (2012) An agricultural pollutant: chemical fertilizer. Int J Environ Sci Dev 3(1):73. https://doi.org/10.7763/ijesd.2012. v3.191

51. Savidov N, Brooks AB (2004) Evaluation and development of aquaponics production and product market capabilities in Alberta. Crop Diversification Centre South, Alberta Agriculture, Food and Rural Development
52. Schmautz Z, Graber A, Jaenicke S, Goesmann A, Junge R, Smits TH (2017) Microbial diversity in different compartments of an aquaponics system. Arch Microbiol 199(4):613-620. https://doi. org/10.1007/s00203-016-1334-1

53. Somerville C, Cohen M, Pantanella E, Stankus A, Lovatelli A (2014) Small-scale aquaponic food production: integrated fish and plant farming. FAO Fisheries and Aquaculture Technical Paper

54. Taiz L, Zeiger E (2002) Photosynthesis: physiological and ecological considerations. Plant Physiol 9:172-174

55. Turcios AE, Papenbrock J (2014) Sustainable treatment of aquaculture effluents-What can we learn from the past for the future? Sustainability 6(2):836-856. https://doi.org/10.3390/ su6020836

56. Van Anrooy R (2002) Marketing opportunities for aquaculture products in the Lesser Antilles. FAO Fisheries Report (FAO)

57. Wahap N, Estim A, Kian AYS, Senoo S, Mustafa S (2010) Producing organic fish and mint in an aquaponic system. Borneo Marine Research Institue, Sabah, pp 29-33

58. Wongkiew S, Hu Z, Chandran K, Lee JW, Khanal SK (2017) Nitrogen transformations in aquaponic systems: a review. Aquacult Eng 76:9-19. https://doi.org/10.1016/j.aquaeng.2017.01.004

59. Wongkiew S, Popp BN, Khanal SK (2018) Nitrogen recovery and nitrous oxide $\left(\mathrm{N}_{2} \mathrm{O}\right)$ emissions from aquaponic systems: influence of plant species and dissolved oxygen. Int Biodeterior Biodegrad 134:117-126. https://doi.org/10.1016/j.ibiod .2018.08.008

60. Wongkiew S, Popp BN, Kim HJ, Khanal SK (2017) Fate of nitrogen in floating-raft aquaponic systems using natural abundance nitrogen isotopic compositions. Int Biodeterior Biodegrad 125:24-32. https://doi.org/10.1016/j.ibiod.2017.08.006

61. Wrage N, Velthof GL, VanBeusichem ML, Oenema O (2001) Role of nitrifier denitrification in the production of nitrous oxide. Soil Biol Biochem 33(12-13):1723-1732. https://doi.org/10.1016/ s0038-0717(01)00096-7

62. Yavuzcan Yildiz H, Robaina L, Pirhonen J, Mente E, Domínguez D, Parisi G (2017) Fish welfare in aquaponic systems: its relation to water quality with an emphasis on feed and faeces-a review. Water 9(1):13. https://doi.org/10.3390/w9010013

63. Yogev U, Barnes A, Gross A (2016) Nutrients and energy balance analysis for a conceptual model of a three loops off grid, aquaponics. Water 8(12):589. https://doi.org/10.3390/w8120589

Publisher's Note Springer Nature remains neutral with regard to jurisdictional claims in published maps and institutional affiliations. 